УДК 811.111 '42

DOI: $10.15421 / 382005$

N. Lysenko

Н. О. Лисенко

Н. А. Лысенко

Oles Honchar Dnipro National University

Дніпровський національний університет імені Олеся Гончара

Днепровский начиональный университет имени Олеся Гончара

\title{
LINGUO-STYLISTIC PECULIARITIES OF THE ENGLISH-LANGUAGE EXPRESSIVE DISCOURSE
}

\section{ЛІНГВОСТИЛІСТИЧНІ ОСОБЛИВОСТІ АНГЛОМОВНОГО ЕКСПРЕСИВНОГО ДИСКУРСУ}

\section{ЛИНГВОСТИЛИСТИЧЕСКИЕ ОСОБЕННОСТИ АНГЛОЯЗЫЧНОГО ЭКСПРЕССИВНОГО ДИСКУРСА}

The article deals with the consideration of different approaches to the study of expressive English discourse, its linguo-stylistic peculiarities. The article presents the views of some linguists on existing varieties of discourse and identifies the place of expressive discourse among them.

In general, discourse is a written or spoken verbal product of a communicative event. Linguists distinguish many different types of discourse, taking into account extralinguistic factors: sociocultural, pragmatic, psychological, etc. In the existing classifications of the typology of discourse the expressive component is indicated, which allows to distinguish a separate kind of discourse - expressive. According to one of the typologies of discourse, there is an expressive type of communicative acts, which is connected with the expression of different feelings, moods, thoughts. According to another classification, an affiliative type of discourse is singled out, which includes the expressive type of speech acts. When investigating expressive discourse, it is necessary to take into account the notion of the expression itself, as well as the notions of expressiveness and emotionality must be distinguished. In scientists' opinion, the emotional in language is needed for the expression of feelings, and the expressive - for enhancing expressiveness and imagery. The relevance of the study of expressive discourse lies in the need to identify the mechanisms for creating expressive effect.

Keywords: expressive English discourse, expressiveness, emotionality, linguo-stylistic means, imagery.

Розглянуто різні підходи до вивчення англомовного експресивного дискурсу, його лінгвостилістичних особливостей. Представлено погляди деяких лінгвістів на існуючі різновиди дискурсу та визначено місце експресивного дискурсу серед них.

У загальному розумінні, дискурс являс собою письмовий або мовний вербальний продукт комунікативної події. Лінгвісти виділяють багато різних типів дискурсу, ураховуючи екстралінгвістичні фактори: соціокультурні, прагматичні, психологічні тощо. У існуючих класифікаціях типології дискурсу так чи інакше зазначається експресивний компонент, що дозволяс виділити окремий різновид дискурсу - експресивний. За однісю 3 типологій дискурсу, виділяють експресивний тип комунікативних актів, який пов'язаний з вираженням різних почуттів, настроїв, думок. За іншою класифікацісю, зазначається афілятивний тип дискурсу, який включає в себе експресивний тип мовленнєвих дій. Досліджуючи експресивний дискурс, необхідно враховувати поняття й самої експресії. Так, експресивність включає в себе виражально-зображальні якості мовлення, що надають йому образності та емоційної забарвленості. Проте, необхідно розрізняти поняття експресивності та емоційності. На думку вчених, емоційне в мові необхідне для вираження почуттів, а експресивне - для підсилення виразності й образності. Актуаль-

(C) Lysenko N., 2020 
ність дослідження експресивного дискурсу полягає в необхідності виявлення механізмів створення експресивного ефекту.

Ключові слова: англомовний експресивний дискурс, експресивність, емоційність, лінгвостилістичні засоби, образність.

Рассмотрены различные подходы к изучению англоязычного экспрессивного дискурса, его лингвостилистических особенностей. Представлены взгляды некоторых лингвистов на существующие разновидности дискурса и определено место экспрессивного дискурса среди них.

В общем понимании, дискурс представляет собой письменный или речевой вербальный продукт коммуникативного события. Лингвисты выделяют много различных типов дискурса, учитывая экстралингвистические факторы: социокультурные, прагматические, психологические и др. В существующих классификациях типологии дискурса так или иначе присутствует экспрессивный компонент, позволяющий выделить отдельный вид дискурса - экспрессивный. По одной из типологий дискурса, выделяют экспрессивный тип коммуникативных актов, который связан с выражением различных чувств, настроений, мыслей. В другой классификации выделяется афилятивний тип дискурса, который включает в себя экспрессивный тип речевых действий. Исследуя экспрессивный дискурс, необходимо учитывать понятие и самой экспрессии. Так, экспрессивность включает в себя выразительно-изобразительные качества речи, которые придают ей образность и эмоциональную окрашенность. Однако, необходимо различать понятия экспрессивности и эмоциональности. По мнению ученых, эмоциональное в языке необходимо для выражения чувств, а экспрессивное - для усиления выразительности и образности. Актуальность исследования экспрессивного дискурса заключается в необходимости выявления механизмов создания экспрессивного эффекта.

Ключевые слова: англоязычный экспрессивный дискурс, экспрессивность, эмоциональность, лингвостилистические средства, образность.

For several decades, the notion of «discourse» has been the object of linguistic research. Being in the field of view of scholars, the term «discourse» constantly acquires various interpretations and is considered in various aspects. In this article we will deal with the most common approaches to the study of discourse in modern linguistics, differentiate between kinds of discourse and identify the place of the expressive discourse in the English language, as well as investigate its linguo-stylistic peculiarities.

Discourse in the broad sense is a complex communicative event that occurs between the speaker and the listener (observer) in a particular context (temporal, spatial, etc.). In the narrow sense, discourse is the «text» or «conversation», that is, a completed or long-lasting «product» of a communicative event, its written or spoken result, which is interpreted by the recipients. Thus, discourse in general terms is a written or linguistic verbal product of a communicative event.

These days, linguists distinguish many different types of discourse, taking into account the related to this phenomenon extralinguistic factors (sociocultural, pragmatic, psychological, etc.). Two major aspects are inalienable components of any discourse classification: the sphere of functioning and the nature of communication. For instance, according to the sphere of functioning, there are academic, business, advertising, pedagogical, and other types of discourse. According to the nature of communication, such types of discourse as formal and informal, teenage, conflict etc. can be mentioned.

According to M. V. Popovych, discourse is «the structure of a speech act together with its context, not as a speech act itself» [3, p. 29]. The researcher examines the typology of discourse in terms of the semiotic approach and proposes such types of communicative acts as cognitive, stimulating and expressive. The first type involves the transmission of 
certain information, the second type is the stimulation of certain actions, and the third type is the expression of different feelings, moods, thoughts (joy, anger, irony, sarcasm, etc.).

S. A. Sukhyh offers a classification of discourse, focusing on the social aspect. At the heart of this classification there are the intentions and goals of the communication participants, their social and personal traits, and the communication environment. Sukhyh distinguishes four types of discourse: interpretative, dialogueinterview, instrumental and affiliative. Interpretative discourse, which can take the form of discussion, is characterized by the ability of one of its participants to get as much information as possible about the other. Dialogue-interview is the distribution of information between participants. Instrumental discourse usually occurs in the manufacturing sphere in the form of instructions, assignments, etc. Affiliative discourse has such traits as personal orientation, expressive (admiration, optimism) and contractual (consent, rejection) types of speech acts [4].

Thus, there are different definitions and classifications of discourse, but most linguists agree that one of the features of this phenomenon is expressiveness, and correspondingly distinguish a separate subtype of discourse such as «expressive discourse». The purpose of this article is to investigate different perspectives on the notion of expression, and to determine the place of expressive discourse in modern linguistics.

O. S. Akhmanova interprets expressiveness as «expressive qualities of speech that distinguish it from the ordinary speech (stylistically neutral), and give it imagery and emotional colouring» [1, p. 324].

Some scholars propose to distinguish between expressiveness and emotionality. For instance, A. M. Emirova believes that the expressive component is «the part of the pragmatic meaning associated with the expression of emotions and evaluations of the speaker» [7, p. 15]. In lexis and phraseology it is the so-called emotional, emotionalevaluative meaning, and in grammar it is subjective-modal meaning. The correlation between emotionality and expressiveness in language is one of the central issues that arise when discussing the problem of emotionality. Some scholars believe that the emotional in language is necessary for the expression of feelings, and the expressive - for enhancing expressiveness and imagery; emotional contrasts intellectual, while expression encompasses both intellectual and emotional. From this point of view, expressiveness is broader than emotionality and includes emotionality as its most important component.

The problem of emotional expression is relevant in linguistics, which deals with language in various aspects of its system organization and function. One of such functions is the inherent ability of the language to realize the emotional intentions of a person. The emotional-expressive semantics of language is one of the specific manifestations of the subjective nature of language. Although the phenomenon of expressiveness can be easily recognized, the mechanisms that create the expressive effect, as well as the factors that create expressive colouring, still need research.

For example,

"Some twenty-five or more years ago, I was enjoying the first flowering of a career I'd spent even more years preparing for. I was finally gaining acceptance as a writer-at first in radio and television» $[8, \mathrm{p} .7]$.

In the example above, the author tries to reinforce the meaning of something that he considers to be very important (in this case, time - «years»), for that the author adds an expressive colour to his message with the help of some elements: «even more years», «finally». In this example expressive load is created with the help of lexical stylistic means. 
Expressiveness in language is the result of such a pragmatic use of language, the main purpose of which is to identify the emotional attitude of the subject of speech to the designated unit and to convey that attitude to the addressee. O. N. Grishina believes that the main source of expressiveness is a work of fiction, because the creation of any message in fiction is always accompanied by the choice of certain linguistic means to ensure aesthetic influence on the reader. With regard to business documents, instructions, etc., such types of texts completely exclude the use of emotions and, therefore, expressiveness. Speaking about the expressiveness of the linguistic message, Grishina insists on considering two different levels: internal and external. The internal level implies expressiveness, which is created by expressive means of speech and stylistic devices. External is the level at which expressiveness is assessed and which requires broad context, that is, when the message acquires expressiveness only in text [5, p. 18].

Sh. Balli can be considered the founder of modern concepts and methods of exploration of expressively coloured speech, who insisted on a multiplicity of means and ways of expressing emotionally coloured one and the same content. V. N. Telia under the expressiveness of speech means its non-neutrality, a deviation that gives it a peculiarity, expressiveness due to the fact that the signal transmitted by the linguistic expression is amplified and thus separated from the common flow or by unusual stylistic use of linguistic means, or as a result of the perception of an associative image that acts as a stimulus for the positive or negative emotional response of the recipient.

For instance,

"It was such a wonderful ordination service at Rochester Cathedral, the second oldest and one of the loveliest cathedrals in the country... The day before had been rainy and miserable, but on this one day the sun shone» [8, p. 136].

The purpose of the author in this example is to convey to the recipient their positive attitude to the subject through the use of adjectives (wonderful) and degrees of comparison of adjectives (loveliest), as well as contrasting different phenomena.

It should also be noted that there are several approaches to determining the place of emotional expression in the theory of language. The dominant is the view on emotionality as on one of the functions of language. The essence of this function is to perform the role of emotional and regulatory nature. This understanding of the emotional function relates it to the main function of language, the communicative one. This is due to one of the common trends in the development of modern science, which lies in the fact that it is predominantly a person at the center of research, as a subject of social and cognitive activity. The place of a person as the subject of speech activity is also being reconsidered in linguistic theory. Change of guidelines has taken place in textual studies as well, with a sharp turn to the pragmatic aspect of the text study. The category of the subject of speech allows to consider the text as a communicative category. The problems of influence of the text and its purposes are brought to the fore. The text consists of statements characterized by the desire to attract the attention of the addressee and by orientation to emotionalexpressive discourse. The role of the addressee is to interpret the message received, that is, to recognize the intentions of its author, which in its turn should elicit the recipient's emotional response. However, according to V. I. Shakhovsky and V. V. Jura, in each case the speaker chooses one or the other point of view on an emotional event. This point of view is always personal, which goes deeply into the speaker's background knowledge and emotional experience, and is therefore not always on a motivated surface for language partners [2, p. 38]. 
Summarizing the points mentioned above, it is possible, first of all, to state that expressive discourse is equally one of the types of discourse. In general, expressiveness is a way of making the speech distinctive and expressive, that is why it is one of the main topics of linguistic research. One of the main functions of expressive discourse is the expression of the emotional intentions of the speaker. With regard to the prospects of this study, it is possible to propose a study of expressive discourse from the perspective of the pragmatic aspect of language. It is essential for the study of this phenomenon to consider the types of text (speech), context and their intended purpose.

\section{References}

1. Akhmanova, O. (2004). Slovar' 5. Iriskhanova K., ed. (1988). Tekst v funkt s lingvisticheskikh terminov. Moscow, P. 571. ional'no-stilevom aspekte. Moskovskii gos.

2. Shahovsky V. \& Zhura V. (2002). Deiksis v sphere emotsional'noy rechevoy deyatel'nosti. Voprosy iazykoznaniia, 5, 38-56 p.

3. Popovych M. (2003). Ponyattya «dyskurs» u metaphizychnomu ta logikolingvistychnomu rozuminni. Filosofs'ka dumka, 1, 27-36 p.

4. Sukhikh S. (1990). Tipologiia iazykovogo obshcheniia. Iazyk, diskurs $i$ lichnost': Mezhvuz. sb. nauch. tr. Tver', 45-50 p. in-t inostrannykh iazykov im. Morisa Toreza, $16-23 \mathrm{p}$.

6. Teliia N., ed. (1991). Chelovecheskii faktor v i a zyke: Iazykovye mekhanizmy ekspressivnosti. In-t iazykoznaniia. P. 214.

7. Emirova A. (1988). Russkai a frazeologii a v kommunikativnom aspekte. Moscow, $15 \mathrm{p}$.

8. Kathy Staff. (1997). My story - wrinkles and all. London: Hodder \& Stoughton.

Надійшла до редакиії 11.10.2019 